\title{
The anatomy of the Late Miocene baleen whale Cetotherium riabinini from Ukraine
}

Pavel Gol'din, Dmitry Startsev, and Tatiana Krakhmalnaya

Acta Palaeontologica Polonica 59 (4), 2014: 795-814 doi: http://dx.doi.org/10.4202/app.2012.0107

We re-describe Cetotherium riabinini, a little-known baleen whale from the Late Miocene of the Eastern Paratethys represented by an exceptionally well-preserved skull and partial skeleton. $C$. riabinini is shown to be closely related to $C$. rathkii, the only other member of the genus. Cetotheriids from the Eastern Paratethys are remarkable for their pachyosteosclerotic postcranial skeleton, and are among the youngest known cetaceans displaying this morphology. C. riabinini likely followed a generalised feeding strategy combining herpetocetine-like continuous suction feeding, as seen in the mallard Anas platyrhynchos, and eschrichtiid-like intermittent suction feeding. This hypothesis may explain the mechanism and function of cranial kinesis in baleen whales. Many characteristics of the mysticete skull likely evolved as a result of cranial kinesis, thus leading to multiple instances of morphological convergence across different phylogenetic lineages.

Key words: Cetacea, Mysticeti, Cetotheriidae, pachyosteosclerosis, suction feeding, cranial kinesis, Miocene, Paratethys, Ukraine.

Pavel Gol'din [pavelgoldin412@gmail.com], Taurida National University, 4, Vernadsky Avenue, Simferopol, Crimea, 95007 Ukraine, current address: Department of Natural History and Palaeontology, The Museum of Southern Jutland, Lergravsvej 2, 6510, Gram, Denmark; Dmitry Startsev [dbstarcev@gmail.com]Taurida National University, 4, Vernadsky Avenue, Simferopol, Crimea, 95007 Ukraine; Tatiana Krakhmalnaya [tv krakhm@mail.ru], Academician V.A. Topachevsky Paleontological Museum of the National Museum of Natural History of the National Academy of Sciences of Ukraine, 15, Bohdan Khmelnitsky St., Kiev, 01601 Ukraine.

This is an open-access article distributed under the terms of the Creative Commons Attribution License (for details please see creativecommons.org), which permits unrestricted use, distribution, and reproduction in any medium, provided the original author and source are credited. 
Forif Full text $(1,246.7 \mathrm{kB})$

Forg Supplementary file $(46.3 \mathrm{kB})$ 